\title{
Big tech and 'the good Samaritans' : a recent precedent on cy pres practices.
}

Camille Akmut

August 10, 2019

\section{Abstract}

UNITED STATES COURT OF APPEALS FOR THE THIRD CIRCUIT. No. 17-1480. IN RE: GOOGLE INC. COOKIE PLACEMENT. 


\section{Introduction}

cy pres... - This, in fact, strange, strange institution.

But, a precedent has just been set by a Federal appeals Court in the U.S.A. that will no doubt be of many consequences to come.

'The good Samaritans', recipient of these awards, various non-profits or university groups, too often entertain questionable relationships with the same companies they should analyze, if not criticize : a little too close for their own good - "troubled" was a recent Court in view of these.

We give this important 2019 precedent with only summary apparatus.

UNITED STATES COURT OF APPEALS FOR THE THIRD

CIRCUIT. No. 17-1480. IN RE: GOOGLE INC. COOKIE

PLACEMENT CONSUMER PRIVACY LITIGATION. Theodore H. Frank, Appellant.

Mandatory reading for all legal scholars, computer scientists, activists and technologists. (In particular pages 24 to 27.)

\section{1 cy pres, a strange institution}

Respectable readers will pardon us, but we cannot help but hear "cash press" in "cy pres".

The origins of the word merit some commentary : cy pres comes from the French, whose modern equivalent would be "si pres" - meaning "so, so close".

And, "so, so close" from some companies are a number of well-known non-profits, whose embarrassing practices of "revolving doors" and "golden parachutes"-like careers had become so obvious we had no choice - against our best will - but to put down on paper, black and white, for everyone to see... A slap on their fingers.

Cindy Cohn and her quarter-million salary... Fred von Lohmann, who even more so than Donna Wentworth, had truly gone wherever the wind blew, so for instance when he worked for the EFF, then Tor, then Google a career progression so bizarre, he should be given the taste of strawberry, chocolate or vanilla milkshake some day...

Alas EPIC, Privacy International and other non-profits which have done considerable work in the shadows of these shadowy characters, do not post cat pictures and are not located in San Francisco (for their own good), and do not have the same air of cool - as a consequence. But, it is to them rather that we would entrust our hopes, if at all - and our money. Better straight and old-fashioned than cool and wishy-washy and bendable.

A total independence should be the standard by which any "cy pres" recipient should be judged, measured by various factors (explicitely not only economic) - should this institution continue to exist.

All in all, what a strange world we were catapulted in, when almost 4 years ago we turned to the world of technology, and started writing a 
work completely independent from the tenets of this culture. Now over 60 publications.

The double employments that are so common here have no parallels in other fields like history or sociology or literature. The modern computer scientist has a 'business on the side', the most normal thing in the world - to them, but to them only.

The rest of us stand bewildered on the side.

\section{References}

Legalists and activists will have a look at the following :

—. 2019. "The Libertarian roots of the EFF."

Based merely on the briefest review of just a few years of activities. A full analysis would reveal likely much more, and break a many hearts. 
the precise benefits that a Rule 23(b)(3) class gives to the defendant and class counsel: namely, a broad class-wide release of claims for money damages for the defendant, and a percentage-of-fund calculation of attorneys' fees for class counsel. The District Court's failure to scrutinize this troubling aspect of the Settlement Agreement prevents us from reviewing its fairness, reasonableness, and adequacy. See Gunter, 223 F.3d at 196 (district court's reasoning and application of the law must be clear enough to provide basis for review). We also question, and leave to the District Court on remand, whether a defendant can ever obtain a class-wide release of claims for money damages in a Rule 23(b)(2) settlement, and if so, whether a release of that kind requires a heightened form of notice either under Rule 23(c)(2)(B) or due process tenets. Cf. NFL Concussion Litig., 821 F.3d at 435 (noting that class action notice must comply with due process); see also In re Payment Card Interchange Fee \& Merchant Discount Antitrust Litig., 827 F.3d 223, 236 (2d Cir. 2016) (reversing district court's approval of Rule 23(b)(2) settlement with broad release); Koby v. ARS Nat'l Servs., 846 F.3d 1071, 1079 (9th Cir. 2017) (same).

\section{b. Cy Pres Recipients}

The District Court held that "the proposed cy pres distributions are appropriately tailored and focused." It found the selected cy pres recipients to be "among the preeminent institutions for researching and advocating for online privacy," and that they would properly be required to use the funds for internet browser privacy initiatives. Id. Because "this case is about Google's alleged circumvention of Internet browser privacy settings," it concluded, the proposed cy pres distributions thus "bear a direct and substantial nexus to the interests of absent class members." The Court made no finding that the class's nationwide nature was reflected in the geographical scope of cy pres recipients' work. See, e.g., 
Schwartz v. Dallas Cowboys Football Club, Ltd., 362 F. Supp. 2d 574, 576 (E.D. Pa. 2005) ("In [reviewing cy pres awards], the court should consider . . the geographic scope of the case."). However, the record shows they overlap; the promotion of better online privacy inherently has nationwide effects.

In sum, on the District Court's review of the record, the proposed cy pres awards would be used for a purpose directly and substantially related to the class's interests. The record also reflects that the geographic scope of the class corresponds to that of the cy pres recipients. The Court held the proposed cy pres awards were fair, reasonable, and adequate when viewed "from the perspective of the Settlement Class as a whole." Although other aspects of its analysis were unusually brief, the Court did not abuse its discretion by approving this (b)(2) class settlement's cy pres structure.

Yet we are troubled here by the selection of the specific cy pres recipients. Frank challenges the selection of those recipients as unfair under Rule 23(e)(2) due to pre-existing associations between them and class counsel or Google. He asserts that Google has long ties to Stanford and is a regular donor and cy pres payor to the Berkeley Center for Law \& Technology, the Berkman Center for Intemet \& Society at Harvard University, the Center for Internet \& Society at Stanford University, and the Center for Democracy \& Technology. One of the lawyers representing the class is also a board member of Public Counsel.

We have not previously addressed when a prior
relationship between a cy pres recipient and one of the litigants in a class action undermines the proposed settlement's fairness. Regardless of the relevant standard, however, the District Court's treatment of the question warrants remand. It conducted no fact finding, either through additional filings or 
an evidentiary hearing, to determine the nature of the relationships between the cy pres recipients and Google or class counsel. In its opinion, the Court misstated the nature of Frank's objections, stating he "takes the position that any relationship between a party (and its counsel) and a proposed cy pres recipient automatically disqualifies the proposed $c y$ pres recipient." It then dismissed the issue in a single sentence with no analysis, holding that "no conflict of interest" had "undermine[d] the selected cy pres recipients." This is not the "scrupulous" examination required of a court acting as a fiduciary for absent class members. See Warfarin Sodium, 391 F.3d at 534; see also Gunter, 223 F.3d at 196.

We further hold that, if challenged by an objector, a district court must review the selected cy pres recipients to determine whether they have a significant prior affiliation with any party, counsel, or the court. A settlement should not be approved if such a prior affiliation "would raise substantial questions . . . whether the selection of the recipient was made on the merits." ALI, Principles of the Law of Aggregate Litigation $\$ 3.07 \mathrm{cmt}$. b. The parties seeking settlement approval bear the burden of explaining to a court why the $c y$ pres selection was fair, which may include describing the nature of any prior affiliations; what role, if any, each affiliation played in the cy pres selection process; whether other recipients were sincerely considered; and why these recipients are the proper choice. As always, "[w] here a court fears counsel is conflicted, it should subject the settlement to increased scrutiny." Baby Prods., 708 F.3d at 173.

On remand, the District Court should consider whether these cy pres recipients have significant prior affiliations with Google, class counsel, or the Court, and, if so, whether the selection process failed to satisfy Rule 23(e)(2) by raising substantial questions whether the recipients were chosen on the merits. Where, as here, the only benefit to class members is a 
cy pres award, parties may also want to involve class members or a neutral participant in the selection of recipients to ward off any appearance of impropriety.

\section{Class Certification}

Frank asserts that, even if his settlement fairness challenge fails, reversal is still appropriate on classcertification grounds. If a settlement will not confer a meaningful benefit to absent class members, he argues it must fail to satisfy Rule 23(a)(4) and (g)(4). Those Rules provide that a class's representative plaintiffs and counsel, respectively, must "fairly and adequately" represent the interests of the class. Frank contends that a cy pres-only settlement in these circumstances confers no benefit on the class, which inherently shows that the class representative and counsel failed to represent the class fairly and adequately. For this reason, he claims a cy pres-only settlement class cannot be certified due to inadequate representation.

Frank's class certification challenge is not really an alternative ground for reversal. It is predicated on his challenge to the settlement. In light of our decision to remand, we leave to the District Court whether to reconsider Frank's contentions concerning the propriety of class certification in light of its further consideration and potential factfinding.

The vista view of this case is not pretty. According to the complaint, an internet behemoth with unprecedented tools for monitoring private conduct told millions of Americans it would not track their personal browser history, and then it did so anyway to profit from the data. Through the proposed classaction settlement, the purported wrongdoer promises to pay a couple million dollars to class counsel and make a cypres 


\title{
PRECEDENTIAL
}

\section{UNITED STATES COURT OF APPEALS}

FOR THE THIRD CIRCUIT

\author{
No. $17-1480$ \\ IN RE: GOOGLE INC. COOKIE PLACEMENT \\ CONSUMER PRIVACY \\ LITIGATION \\ Theodore H. Frank, \\ Appellant

\begin{abstract}
Appeal from the United States District Court
for the District of Delaware

(D.C. Civil Action No. 1-12-md-02358)

District Judge: Honorable Sue L. Robinson
\end{abstract}

Argued November 14, 2017

Before: AMBRO, KRAUSE, and RENDELL, Circuit Judges

(Opinion filed: August 6, 2019)

Theodore H. Frank (Argued)

Adam E. Schulman 